\title{
SOIL CHARACTERISTICS OF DRY LAND IN INDRAPURI AND BLANG BINTANG SUB- DISTRICTS OF ACEH BESAR REGENCY, ACEH PROVINCE, INDONESIA
}

\author{
Irmansyah T. ${ }^{1 *}$, Rauf A. ${ }^{2}$, Delvian ${ }^{3}$, Akoeb E.N. ${ }^{2}$ \\ ${ }^{1}$ Doctoral Student in Agricultural Science, Universitas Sumatera Utara, Padang Bulan, \\ Medan, Indonesia \\ ${ }^{2}$ Agricultural Science, Universitas Sumatera Utara, Padang Bulan, Medan, Indonesia \\ ${ }^{3}$ Faculty of Forestry, Universitas Sumatera Utara, Padang Bulan, Medan, Indonesia \\ ${ }^{*}$ E-mail: teuku.irmansyah.teungoh@gmail.com
}

\begin{abstract}
Using of critical land for agricultural cultivation must be done carefully and wisely, given the status of the land itself which has vulnerability. The first step that can be done is to analyse the soil properties that are important and related to plant growth factors, especially the chemical and physical properties of soils which directly affect plant growth. The purpose of this study is to describe the characteristics of critical dry land in Indrapuri and Blang Bintang Sub-district, Aceh Besar Regency, Aceh Province. The research method was used a field survey covering the area of Indrapuri and Blang Bintang Sub-districts. The descriptive analysis was done for the field data and laboratory obtained. Soil samples that have been taken from the field before being analyzed are air dried for 1 week, after that they are ground and sieved using 2.0 sieves for soil texture analysis and using $0.5 \mathrm{~mm}$ sieves for analysis of soil chemical properties such as $\mathrm{pH}$, C-organic, exchangeable cations (Ca-dd, Mg-dd, K-dd, and Na-dd), cations exchange capacity (CEC), base saturation (KB), total nitrogen, and $\mathrm{P}_{2} \mathrm{O}_{5}$. The finding of this study is there are 3 categories of critical land in Blang Bintang Subdistrict, namely critical potential of 2,027 ha, critical land of 861 ha, and very critical land with an area of 1,341 ha. Land in the agricultural cultivation area in Indrapuri Sub-district has 3 (three) levels of land criticality, namely: uncritical land area of 5,280 ha, rather critical land area of 6,562 ha, and critical area of 3,135 ha. Land with varying degrees of criticality in Blang Bintang and Indrapuri Sub-districts is generally has very low to low soil fertility.
\end{abstract}

\section{KEY WORDS}

Soil characteristics, critical land, soil fertility.

Currently, national food production continuously to decline due the increasingly of narrow productive agricultural land. An alternative choice that is expected to increase of potential crop production in order to meet food needs is the use of critically dry land. Statistics data show that critical land in Indonesia, not least in Aceh Province continues to grow every year which results in the reduction of productive land area and in turn can threaten food security and sustainability and environmental sustainability, therefore, efforts are needed to save critical dry land that can have a detrimental impact on agricultural production and the environment.

Dry land occupies about $40 \%$ of the Earth's land surface (White and Nackoney 2003), in sub-humid, semi-arid and arid conditions according to the ratio of average annual rainfall to potential evapotranspiration. The area of critical land in Aceh Province in 2010 reached $1,823,533$ hectares (Mahyuddin et.al, 2013), an increase compared to the area of critical land in 2002 which was $860,659.93$ ha, with details: very critical 5,777 ha, critical 320,248.13 ha, rather critical 96,738.29 ha, and potentially critical 437,896.51 ha (Bukhari and Febryano, 2010). Whereas, in Aceh Besar Regency, the area of critical land reaches 31,319 ha with a distribution of 8,878 ha inside the forest area and 22,171 ha on outside the forest area (BPS, Aceh Besar in Figures 2018). The total area with various degrees of critical land status in the study area is 24,176 ha, where is 4,229 ha spread across Blang Bintang Sub-district and 19,947 ha in Indrapuri Sub-district (Bappeda Aceh, 2013). 
However, the use of critical land for agricultural cultivation must be done carefully and wisely, given the status of the land itself which has vulnerability. The first step that can be done is to analyse the soil properties that are important and related to plant growth factors, especially the chemical and physical properties of soils which directly affect plant growth. The purpose of this study is to describe the characteristicts of critical dry land in Indrapuri and Blang Bintang Sub-district, Aceh Besar Regency, Aceh Province.

\section{METHODS OF RESEARCH}

The research method was used a field survey covering the area of Indrapuri and Blang Bintang Sub-districts. The descriptive analysis was done for the field data and laboratory obtained. Field surveys and soil sampling are conducted following the direction of Mukhlis (2018), using zigzag and composite methods, where at each point soil samples were taken approximately $1-2 \mathrm{~kg}$. Then soil samples from each point in an area are mixed (composite) evenly, then taken as much as $\pm 1.5 \mathrm{~kg}$, put into a plastic bag and labeled field. Soil taken for chemical soil analysis samples in the laboratory is the top soil $(0-30 \mathrm{~cm}$ layer). Soil samples that have been taken from the field before being analysed are air dried for 1 week, after that they are ground and sieved using 2.0 sieves for soil texture analysis and using $0.5 \mathrm{~mm}$ sieves for analysis of soil chemical properties such as $\mathrm{pH}$, C-organic, exchangeable cations (Ca-dd, Mg-dd, K-dd, and Na-dd), cations exchange capacity (CEC), base saturation (KB), total nitrogen, and $\mathrm{P}_{2} \mathrm{O}_{5}$. Soil analysis methods and procedures are guided by procedures issued by the Bogor Soil Research Center (2009):

\begin{tabular}{|l|l|l|}
\hline NO & SOIL CHEMICAL PROPERTIES & METHOD OF ANALYSIS \\
\hline 1 & PH & PH METER (ELECTROMETRIC) \\
\hline 2 & C-ORGANIK & WALKLEY AND BLACK \\
\hline 3 & N-TOTAL & KJELDAHL \\
\hline 4 & P2O5 & EXTRACTION HCL $25 \%$ \\
\hline 5 & K_DD & EXTRACTION HCL $25 \%$ \\
\hline 6 & EXCHANGEABLE CATIONS & EXTRACTION $1 \mathrm{~N} \mathrm{NH4COOCH3PH} 7$ \\
\hline 7 & CATIONS EXCHANGE CAPACITY & EXTRACTION $1 \mathrm{~N} \mathrm{NH4COOCH3PH} 7$ \\
\hline 8 & BASE SATURATION & KATION BASA/KTK $100 \%$ \\
\hline
\end{tabular}

The data that has been collected is analysed through qualitative and quantitative approaches. The results are interpreted and then seen the trends in the characteristics of the conditions. The method of work undertaken for the analysis of degraded land is based on the Technical Guidelines for the Compilation of Critical Land Spatial Data in 2004 by the Directorate General of RLPS No. S.296 / V-SET / 2004 dated October 5, 2004. Basically, the technique used in this analysis is the overlay method and direct survey in the field.

\section{RESULTS AND DISCUSSION}

The condition of dry land in the study location is presented in Table 1, it's can be seen that the chemical properties of the soil in the research area are generally very low to moderate. The soil $\mathrm{pH}$ conditions that netral are not followed by base saturation, where the levels is low to moderate. This condition illustrates that the level of soil fertility on critical dry land in Aceh Besar Regency is low. The highly $\mathrm{pH}$ level is made possible by the accumulation of salts, especially $\mathrm{Na}$ and $\mathrm{Ca}$ which are classified as moderately due to high soil evaporation, because the study site is classified as dry land with high temperature with little rainfall.

In accordance with the critical condition of the land, C-organic content in the field study area is in the very low category, which is $0.75-0.9 \%$. Low levels of C-organic in dry land are caused by highly weathering and washing due to high air temperatures, reduced vegetation cover, thereby reducing the supply of coarse organic material. C-Organic conditions in dry land areas in Aceh Besar are generally quite uniform, as reported by Martunis et.al (2017), Kautsar et.al (2018) and Ferdeanty et.al (2019). Furthermore, N-total content in the dry land 
of Aceh Besar District is in range of very low - low. This gives an indication that one of the problems found in dry land in Aceh Besar District is soil fertility has low.

Table 1 - Soil Characteristics of dry land in Indrapuri and Blang Bintang Sub-districts, Aceh Besar District

\begin{tabular}{|c|c|c|c|c|c|c|c|c|c|c|}
\hline & \multicolumn{10}{|c|}{ Soil Characteristics } \\
\cline { 2 - 11 } & $\mathrm{pH}$ & $\begin{array}{c}\mathrm{C}- \\
\text { organic } \\
(\%)\end{array}$ & $\begin{array}{c}\mathrm{N}- \\
\text { total } \\
(\%)\end{array}$ & $\begin{array}{c}\mathrm{P}_{2} \mathrm{O}_{5} \\
(\mathrm{ppm})\end{array}$ & $\begin{array}{c}\mathrm{K} \\
(\mathrm{me} / 100 \\
\mathrm{g})\end{array}$ & $\begin{array}{c}\mathrm{Na} \\
(\mathrm{me} / 100 \\
\mathrm{g})\end{array}$ & $\begin{array}{c}\mathrm{Ca} \\
(\mathrm{me} / 100 \\
\mathrm{g})\end{array}$ & $\begin{array}{c}\mathrm{Mg} \\
(\mathrm{me} / 100 \\
\mathrm{g})\end{array}$ & $\begin{array}{c}\mathrm{KTK} \\
(\mathrm{me} / 100 \\
\mathrm{g})\end{array}$ & $\begin{array}{c}\mathrm{KB} \\
(\%)\end{array}$ \\
\hline $\begin{array}{c}\text { Indrapuri } \\
\text { Sub-district }\end{array}$ & $\begin{array}{c}7.23 \\
(\mathrm{~N})\end{array}$ & $\begin{array}{c}0.90 \\
(\mathrm{VL})\end{array}$ & $\begin{array}{c}0.16 \\
(\mathrm{~L})\end{array}$ & $\begin{array}{c}1.71 \\
(\mathrm{~L})\end{array}$ & $\begin{array}{c}0.29 \\
(\mathrm{~L})\end{array}$ & $\begin{array}{c}0.54 \\
(\mathrm{M})\end{array}$ & $\begin{array}{c}9.24 \\
(\mathrm{M})\end{array}$ & $\begin{array}{c}0.81 \\
(\mathrm{~L})\end{array}$ & $\begin{array}{c}17.50 \\
(\mathrm{M})\end{array}$ & $\begin{array}{c}34 \\
(\mathrm{~L})\end{array}$ \\
\hline $\begin{array}{c}\text { Blang } \\
\text { Bintang }\end{array}$ & 7.11 & 0.75 & 0.08 & 1.56 & 0.37 & 0.47 & 10.25 & 0.87 & 16.60 & 45.7 \\
Sub-district & $(\mathrm{N})$ & $(\mathrm{VL})$ & $(\mathrm{VL})$ & $(\mathrm{VL})$ & $\begin{array}{c}\mathrm{L}) \\
(\mathrm{M})\end{array}$ & $\begin{array}{c}\mathrm{M}) \\
(\mathrm{M})\end{array}$ & $\begin{array}{c}4 \\
(\mathrm{M})\end{array}$ \\
\hline
\end{tabular}

Note: Criteria for assessment of soil chemical properties based on the Indonesian Ministry of Agriculture's agricultural research and development agency, 2012. N: Neutral M: Moderate; VL: Very Low, L: Low.

Organic matter in the form of C-organic soil is very influential in the ability of the soil to maintain soil fertility and productivity through the activity of soil microorganisms. Soil organic matter is a central element in soil fertility, land productivity and land quality (Katyal and Reddy, 2001). Even in sustainable agriculture, C-organic soil is a characteristic of soil that is used as an indicator of sustainable natural resources (Agus et al. 2001). Therefore (Tolaka 2013) asserted, the addition of organic material absolutely must be given because organic material is very instrumental in creating fertile soil conditions. Organic material is also a major source of humus colloidal formation (Sufardi, 2012).

Table 2 - Condition of land cover in Blang Bintang and Indrapuri Sub-districts, Aceh Besar Regency

\begin{tabular}{|c|c|c|c|c|c|c|}
\hline \multirow{3}{*}{ Sub-district } & \multicolumn{5}{|c|}{ Area and percentage of canopy cover / category / (score) } & \multirow{3}{*}{$\begin{array}{c}\text { Area (ha) } \\
(\%)\end{array}$} \\
\hline & $>80$ & $60-80$ & $41-60$ & $21-40$ & $<20$ & \\
\hline & 5 (VG) & $4(\mathrm{G})$ & $3(\mathrm{M})$ & $2(\mathrm{P})$ & $1(\mathrm{VP})$ & \\
\hline Blang Bintang & $\begin{array}{c}385 \\
(9.10 \%)\end{array}$ & $\begin{array}{c}334 \\
(7.90 \%)\end{array}$ & $\begin{array}{c}1.388 \\
(32.82 \%)\end{array}$ & $\begin{array}{c}1.376 \\
(32.54 \%)\end{array}$ & $\begin{array}{c}746 \\
(17.64 \%)\end{array}$ & $\begin{array}{c}4.229 \\
(100 \%)\end{array}$ \\
\hline Indrapuri & $\begin{array}{c}3.511 \\
(17.60 \%)\end{array}$ & $\begin{array}{c}5.657 \\
(28.36 \%)\end{array}$ & $\begin{array}{c}5.448 \\
(27.31 \%)\end{array}$ & $\begin{array}{c}2.452 \\
(12.29 \%)\end{array}$ & $\begin{array}{c}2.879 \\
(14.43 \%)\end{array}$ & $\begin{array}{l}19.947 \\
(100 \%)\end{array}$ \\
\hline Total (ha) & 3.896 & 5.991 & 6.836 & 3.828 & 3.625 & 24.176 \\
\hline
\end{tabular}

Note: $V G=$ Very good, $G=$ Good, $M=$ Medium, $P=$ Poor, $V P=$ Very Poor.

Based on Table 2 it is known that the condition of land cover in very good condition, covered by $>80 \%$. In Blang Bintang and Indrapuri Sub-district reached $9.11 \%$ and $17.60 \%$ of the total area of each area. The percentage of land cover conditions in the excellent category in Indrapuri Sub-district, is greater than Blang Bintang Sub-district. While the percentage of land cover in the bad to very bad category in Blang Bintang Sub-district is $50.19 \%$ of the total area of the sub-district. Whereas in Indrapuri Sub-district the percentage of land cover in the bad to very bad category only reached $26.72 \%$ of the total area of the Sub-district area. Thus it can be concluded that the percentage of land cover in the bad to very bad category in Blang Bintang Sub-district is wider than Indrapuri Sub-district.

Based on the data in Table 3, it is known that the critical land in Blang Bintang and Indrapuri Sub-districts which have a slope of more than $31 \%$ reaches 9,692 ha. These lands generally have a very large risk or limiting factor for annual crop development. The distribution of land within the slope class $>31 \%$ are 799 ha $(18.89 \%)$ in Blang Bintang sub district and 8,893 ha (44.59\%) in Indrapuri Sub-district. Slopes are factors that determine the ability of land and the suitability of commodities to be cultivated in an area. The slope of a land is related to erosion, so if land use is not in accordance with the physical condition of the land it will cause soil erosion. If land is not an obstacle, flat land with slopes up to $8 \%$ can be used for intensive agriculture such as annual crop farming. If the soil is poorly drained so the 
soil continues to get wet throughout the year, it should be used for rice fields. While the sloping land with slopes between $8-15 \%$ can be cultivated for agroforestry.

Table 3 - Slope classes distribution in Blang Bintang and Indrapuri Sub-districts, Aceh Besar Regency

\begin{tabular}{|c|c|c|c|c|c|c|}
\hline \multirow[b]{2}{*}{ Sub-district } & \multicolumn{5}{|c|}{ Slope classes } & \multirow[b]{2}{*}{$\begin{array}{l}\text { Large of area } \\
\quad(\mathrm{ha} / \%)\end{array}$} \\
\hline & $\begin{array}{l}0-8 \\
(F)\end{array}$ & $\begin{array}{l}9-15 \\
(S)\end{array}$ & $\begin{array}{c}16-30 \\
\text { (SS) }\end{array}$ & $\begin{array}{c}31-40 \\
\text { (S) }\end{array}$ & $\begin{array}{l}>40 \\
\text { (VS) }\end{array}$ & \\
\hline Blang Bintang & $\begin{array}{c}1.624 \\
(38.40 \%) \\
\end{array}$ & $\begin{array}{c}619 \\
(14.64 \%) \\
\end{array}$ & $\begin{array}{c}1.187 \\
(28.07 \%) \\
\end{array}$ & $\begin{array}{c}546 \\
(12.91 \%) \\
\end{array}$ & $\begin{array}{c}253 \\
(5.98 \%) \\
\end{array}$ & $\begin{array}{c}4.229 \\
(100 \%) \\
\end{array}$ \\
\hline Indrapuri & $\begin{array}{c}4.402 \\
(22.07 \%)\end{array}$ & $\begin{array}{c}972 \\
(4.87 \%) \\
\end{array}$ & $\begin{array}{c}5.680 \\
(28.48 \%) \\
\end{array}$ & $\begin{array}{c}2.662 \\
(13.35 \%) \\
\end{array}$ & $\begin{array}{c}6.231 \\
(31.24 \%) \\
\end{array}$ & $\begin{array}{l}19.947 \\
(100 \%) \\
\end{array}$ \\
\hline Total (ha) & 6.026 & 1.591 & 6.867 & 3.208 & 6.484 & 24.176 \\
\hline
\end{tabular}

Note: $F=$ Flat,$S=$ Sloping, $S S=$ Slightly Steady, $S=$ Steep, and VS = Very Steep.

Table 4 presents the results of field observations on the level of soil erosion and area distribution based on the level of erosion in Blang Bintang and Indrapuri Sub-district, Aceh Besar Regency. Based on Table 4 it can be seen that the percentage of land area with a very heavy erosion status in Blang Bintang Sub-district is greater (14.87\%) compared to Indrapuri Sub-district, which is only $7.40 \%$ of the total area of sub-districts

Table 4 - Land conditions based on erosion rates in Blang Bintang and Indrapuri Sub-district, Aceh Besar Regency

\begin{tabular}{|c|c|c|c|c|c|}
\hline \multirow{2}{*}{ Sub-district } & \multicolumn{4}{|c|}{ Erosion } & \multirow{2}{*}{$\begin{array}{c}\text { Large of area } \\
\text { (ha/\%) }\end{array}$} \\
\hline & Slight & Moderate & Severe & Very heavy & \\
\hline Blang Bintang & $\begin{array}{c}1.151 \\
(27.22 \%) \\
\end{array}$ & $\begin{array}{c}1.128 \\
(26.67 \%) \\
\end{array}$ & $\begin{array}{c}1.321 \\
(31.24 \%) \\
\end{array}$ & $\begin{array}{c}629 \\
(14.87 \%) \\
\end{array}$ & $\begin{array}{c}4.229 \\
(100 \%) \\
\end{array}$ \\
\hline Indrapuri & $\begin{array}{c}9.443 \\
(47.34 \%)\end{array}$ & $\begin{array}{c}5.004 \\
(25.09 \%)\end{array}$ & $\begin{array}{c}4.024 \\
(20.17 \%)\end{array}$ & $\begin{array}{c}1.476 \\
(7.40 \%)\end{array}$ & $\begin{array}{l}19.947 \\
(100 \%)\end{array}$ \\
\hline Total (ha) & 10.594 & 6.132 & 5.345 & 2.105 & 24.176 \\
\hline
\end{tabular}

Table 5 - Distribution of area based on the level of land productivity in Blang Bintang and Indrapuri Sub-districts, Aceh Besar Regency

\begin{tabular}{|c|c|c|c|c|c|}
\hline \multirow{2}{*}{ Sub-district } & \multicolumn{4}{|c|}{ Land productivity } & \multirow{2}{*}{$\begin{array}{c}\text { Large of area } \\
\text { (ha/\%) }\end{array}$} \\
\cline { 2 - 5 } & High & Moderate & Low & Very Low & 4.229 \\
\multirow{2}{*}{ Blang Bintang } & 521 & 2.321 & 758 & 629 & $(100 \%)$ \\
\hline \multirow{2}{*}{ Indrapuri } & $(12.31 \%)$ & $(54.88 \%)$ & $(17.92 \%)$ & $(14.87 \%)$ & 19.947 \\
& 7.735 & 9.203 & 3.009 & 0 & $(100 \%)$ \\
\hline Total (ha) & $(38.78 \%)$ & $(46.14 \%)$ & $(15.08 \%)$ & $(0 \%)$ & 24.176 \\
\hline
\end{tabular}

Table 5 shows that an area of 521 ha $(12.31 \%)$ of the total area of Blang Bintang Subdistrict, has a high level of land productivity, and 1,387 ha $(32.79 \%)$ of the total land area in Blang Bintang Sub-district belongs to the category of low productivity to very low. While the level of land productivity in Indrapuri Sub-district is known to be 7,735 ha (38.78\%) of the total area of this sub-district has a high land productivity status, and 3,009 ha $(15.05 \%)$ belongs to the category with low to very low productivity levels.

Table 6 - Area of land distribution based on applied levels of land management in Blang Bintang and Indrapuri Sub-districts, Aceh Besar Regency

\begin{tabular}{|c|c|c|c|c|}
\hline \multirow[b]{2}{*}{ Sub-district } & \multicolumn{3}{|c|}{ Land management description and class } & \multirow[b]{2}{*}{$\begin{array}{l}\text { Large of area } \\
\qquad(\mathrm{ha} / \%)\end{array}$} \\
\hline & $\begin{array}{c}\left.\text { Complete }^{\star}\right) \\
\text { (Well) }\end{array}$ & $\begin{array}{c}\text { Incomplete } \\
\text { (Medium) }\end{array}$ & $\begin{array}{l}\text { None } \\
\text { (Bad) }\end{array}$ & \\
\hline Blang Bintang & $\begin{array}{c}0 \\
(0 \%) \\
\end{array}$ & $\begin{array}{c}2.060 \\
(48.71 \%) \\
\end{array}$ & $\begin{array}{c}2.169 \\
(51.29 \%) \\
\end{array}$ & $\begin{array}{c}4.229 \\
(100 \%)\end{array}$ \\
\hline Indrapuri & $\begin{array}{c}5.279 \\
(26.47 \%)\end{array}$ & $\begin{array}{c}2.297 \\
(11.52 \%)\end{array}$ & $\begin{array}{c}12.371 \\
(62.02 \%)\end{array}$ & $\begin{array}{l}19.947 \\
(100 \%)\end{array}$ \\
\hline Total (ha) & 5.279 & 4.357 & 314.540 & 24.176 \\
\hline
\end{tabular}


Table 6 shows that in Blang Bintang Sub-district the areas that were not implemented in complete management in their management reached $48.71 \%$ and $51.29 \%$ without implementing management in land management. The same thing is also seen in the Indrapuri sub-district, where there is had no management application, reaching $62.02 \%$ and only $26.47 \%$ have implemented good land management.

The results of the study can cover the entire area with varying degrees of criticism of land in Blang Bintang and Indrapuri Sub-district 24,176 ha, which are spread out in Blang Bintang Sub-district covering 4,229 ha and 19,947 ha in Indrapuri Sub-district. The details can be seen in Tables 7 and 8.

Table 7 shows the level of land criticality based on the multiplication between the weights and the score of each component of the land criticality assessment parameters in Blang Bintang Sub-district, Aceh Besar District. It is known that in the cultivation area for agriculture in Blang Bintang Sub-district there are 4 (four) classes of land critical levels with varying extent of very critical, critical, somewhat critical, and critical potential. In addition, it is also known that in Blang Bintang Sub-district relatively no land is found in agricultural cultivation areas with uncritical categories.

Table 7 - Distribution of critical land in cultivation areas for agricultural business in Blang Bintang Sub-district, Aceh Besar Regency

\begin{tabular}{|c|c|c|c|c|c|}
\hline \multirow{2}{*}{ No } & Criteria Value & \multirow{2}{*}{$\begin{array}{c}\text { Value of Analysis } \\
\text { (Weight } x \text { Score) }\end{array}$} & \multicolumn{2}{c|}{ Classes } & \multicolumn{2}{c|}{ Large of area } \\
\cline { 3 - 6 } & $426-500$ & - & Uncritical & - & Ha \\
\cline { 2 - 6 } & $351-425$ & $360-380$ & Critical Potential & 2.027 & 47.93 \\
\cline { 2 - 6 } & $276-350$ & - & Rather critical & - & - \\
\hline 3 & $201-275$ & $210-210$ & Critical & 861 & 20.36 \\
\hline 4 & $115-200$ & $120-190$ & Very critical & 1.341 & 31.71 \\
\hline \multicolumn{2}{|r|}{} & \multicolumn{2}{|c|}{ Total } & 4.229 & 100 \\
\hline
\end{tabular}

Table 8 - Distribution of critical land in cultivation areas for agricultural landuse in Indrapuri Sub-district, Aceh Besar Regency

\begin{tabular}{|c|c|c|c|c|c|}
\hline \multirow{2}{*}{ No } & Criteria Value & $\begin{array}{c}\text { Value of Analysis } \\
\text { (Weight } x \text { Score })\end{array}$ & Classes & \multicolumn{2}{|c|}{ Large of area } \\
\cline { 3 - 6 } & $426-500$ & $470-470$ & Uncritical & 5.280 & 26.47 \\
\hline & $351-425$ & - & Critical Potential & - & - \\
\hline 2 & $276-350$ & $290-320$ & Rather critical & 6.562 & 32.90 \\
\hline 3 & $201-275$ & $220-260$ & Critical & 3.135 & 15.71 \\
\hline 4 & $115-200$ & - & Very critical & - & - \\
\hline 5 & \multicolumn{2}{r|}{ Protected area } & & 4.970 & 24.92 \\
\hline
\end{tabular}

Table 8 shows that there are 3 (three) categories of critical land in the cultivation area for agricultural business in Indrapuri Sub-district, Aceh Besar Regency, namely uncritical, somewhat critical, and critical land. In addition, it is also known that lands with the category of critical and very critical potential have not been detected in the cultivation area for agriculture in Indrapuri Sub-district, Aceh Besar Regency. When viewed from the organic material content (very low), the soil in the study location is classified as critical. The criticality of the soil is also reflected in the levels of nutrients $\mathrm{N}, \mathrm{P}, \mathrm{K}$ and $\mathrm{Mg}$ which are classified as low to very low (Table 1).

\section{CONCLUSION}

Based on field observations and laboratory analysis, it's can be concluded that there are 3 (three) categories of critical land in Blang Bintang Sub-district, namely critical potential of 2,027 ha, critical land of 861 ha, and very critical land with an area of 1,341 ha. Land in the agricultural cultivation area in Indrapuri Sub-district has 3 (three) levels of land criticality, namely: uncritical land area of 5,280 ha, rather critical land area of 6,562 ha, and critical area 
of 3,135 ha. Land with varying degrees of criticality in Blang Bintang and Indrapuri Subdistricts is generally has very low to low soil fertility.

\section{REFERENCES}

1. Agus, F., M. V. Noordwijk \& D. Garrity. 2001. Technical and Institutional Innovations for Environmentally Sustainable Agriculture. International Center for Research in Agroforestry, Bogor.

2. Bappeda Aceh, 2013. Study of the Utilization of Critical Land in Aceh Besar, collaboration between Bappeda Aceh - Study Program of Magister of Land Resources Conservation Syiah Kuala University.

3. BPS. 2019. Aceh Besar in Figures 2019. Central Statistics Agency. Aceh Besar.

4. Bukhari \& Febryano, I.G. 2010. Design of Agroforestry in Critical Land: Case Study in Indrapuri Subdistrict, Aceh Besar District. Jurnal Perennial, 6(1): 53-59.

5. Ferdeanty, Sufardi \& Arabia, T. 2019. Characteristics Morphology and Soil Classification of Andisol at Dry Land in Aceh Besar District. Jurnal IImiah Mahasiswa Pertanian 4(4):666-676.

6. Katyal, J.C., N.H. Rao, \& M.N. Reddy. 2001. Critical aspects of organic matter management in the Tropics: the example of India. Nutrient Cycling in Agroecosystems.

7. Kautras, L., Ilyas \& Sufardi. 2018. Characteristics of Charge and Soil Physicochemical Properties of Ultisol and Andisol in Dry land of Aceh Besar. Jurnal Ilmiah Mahasiswa Pertanian 3(2):409-419.

8. Mahyuddin, Sugianto, Alvisyahrin, T. 2013. Forest Land Cover Analysis of Krueng Aceh Watershed in Pre and Post-Tsunami. Jurnal Manajemen Sumberdaya Lahan 2(3): 296303.

9. Martunis, Sufardi \& Muyassir. 2017. Chemical Characteristics and Soil Fertility Status of Several Types of Soil in Dry Land of Aceh Besar, Aceh. J. Agrotan 3(1): 77- 90.

10. Mukhlis. 2018. Soil and plant analysis, USU press, 2nd edition.

11. Tolaka. W. 2013. Sifat Fisik Tanah pada Hutan Primer, Agroforestri dan Kebun Kakao di Sub-DAS Wera Saluopa. Desa Leboni. Kecamatan Pamina, Peselemba Kabupaten Poso. Jurusan Kehutanan, Fakultas Kehutanan, Universitas Tadulako. Warta Rimba 1(1).

12. White R.P \& Nackoney, J. 2003. Dry lands, people and ecosystem goods and services. World Resources Institute, Washington. 